\title{
Drivers of Value Creation in the Brazilians Private Higher Education Institutions: The Deans' Perspectives
}

\author{
Jose Francisco De Carvalho Rezende ${ }^{1}$, Claudio Marcos Maciel Da Silva ${ }^{2}$, Bruno Cezar Pinto Aderne Gomes ${ }^{1} \&$ \\ Alessandro Marinho Pinheiro ${ }^{3}$ \\ ${ }^{1}$ Grande Rio University (UNIGRANRIO), Brazil \\ ${ }^{2}$ Estacio de Sa University (UNESA), Brazil \\ ${ }^{3}$ UNISUAM, Brazil \\ Correspondence: Claudio Marcos Maciel Da Silva, Estacio De Sa University, Brazil.
}

Received: November 13, 2016

doi:10.5430/ijba.v8n1p34
Accepted: November 29, $2016 \quad$ Online Published: December 19, 2016

URL: http://dx.doi.org/10.5430/ijba.v8n1p34

\begin{abstract}
This research aimed to identify the drivers regarding performance and value creation in Higher Education Institutions (HEI). As theoretical framework, this study has used, as the concept of Value, the Intellectual Capital and the Financial Capital and respective application possibilities in Higher Education. The answers obtained came from Deans of a Brazilian private HEI, which offers educational services to a target public mostly represented by students from classes $\mathrm{C}$ and D. By means of the survey data, subjects were categorized into three clusters: Academic, Corporative and Operative. Each of these profiles provides a different view of the drivers that create value to the HEI's strategy and operations.
\end{abstract}

Keyswords: higher education institutions, intellectual capital, performance management, value creation

\section{Introduction}

For the past fifteen years, the growth in the education industry in Brazil, specifically concerning to the Higher Education Institutions (HEI), led to profound transformations upon the idea of value creation. This brings implications on the confrontation between strategies and practices observed in the family business educational groups versus the ones in which the control lies upon a conglomerate (INEP, 2013).

As it happens to all activities facing expansion, the growth in education industry brought up the arrival of new players, and therefore, increasing competition trough the diversification of the offers and alternatives for the prospects, since there are more private HEI running businesses (INEP, 2013).

The main economic support mechanism of this scenario turned out to be the cash flow generation, based on gaining and keeping the students. The competition arena led to an endless number of private HEI providing courses with low fees, in order to increase the number of new students via the stretching of price-demand relation. Business models that allow the optimization of resources as would reach the economy of scale and the operational efficiency: students per class, common subjects sharing among different courses, extreme cost control of the professors' wages. In synthesis, not a strategical thinking, but one based essentially upon the operational efficiency.

However, such approach implies in a permanent and complex scanning of the offer conditions. As the education industry in Brazil is a too regulated economic activity, courses with improper offer conditions might suffer punishments from the regulation entity (Ministry of Education), such as the reduction of the number of vacancies or even closing the institution.

The Deans, whose performance regards operational activities in a HEI, play a relevant role upon the leading of this managerial focus: they're in charge for handling the incoming of prospect students, in offer conditions harmonically under the requirements of the government ruler entity. 
Exhibit 1. Laws and restrictions regarding the HEI

\begin{tabular}{|c|c|c|}
\hline Law & Subject & Restrictions \\
\hline $\begin{array}{l}\text { Normative } \\
\text { Ordinance } n^{\text {o }} 01 \\
\text { January } 22^{\text {nd }} 2010\end{array}$ & $\begin{array}{l}\text { Government funds for } \\
\text { financing undergraduate } \\
\text { students (FIES) }\end{array}$ & $\begin{array}{l}\text { Bad courses' assessments make government } \\
\text { financing tuitions not available to students and } \\
\text { prospects of the HEI }\end{array}$ \\
\hline $\begin{array}{l}\text { Federal Law } 11.096 \\
\text { January } 13^{\text {th }} 2005\end{array}$ & $\begin{array}{l}\text { Government funds for } \\
\text { undergraduate } \\
\text { scholarships (PROUNI) }\end{array}$ & $\begin{array}{l}\text { If the IES presents for two cycles a performance } \\
\text { assessment (SINAES) considered insufficient, the } \\
\text { Ministry of Education will not grant additional } \\
\text { scholarships for the admission of new students. }\end{array}$ \\
\hline $\begin{array}{l}\text { Normative } \\
\text { Ordinance } \mathrm{n}^{\mathrm{o}} 40 \\
\text { December } 12^{\text {th }} 2007\end{array}$ & $\begin{array}{l}\text { Rules for IES } \\
\text { authorization renewal } \\
\text { and course certification }\end{array}$ & $\begin{array}{l}\text { Interruption of the regulation processes in } \\
\text { progress, prohibition of new set-up processes and } \\
\text { limitation of new students for the HEI obtaining } \\
\text { ICG under score } 3 \text {. }\end{array}$ \\
\hline $\begin{array}{l}\text { MEC's Normative } \\
\text { Ordinance } n^{\circ} 160 \\
\text { March } 5^{\text {th }} 2013\end{array}$ & $\begin{array}{l}\text { Offer of technical } \\
\text { courses of initial, } \\
\text { intermediate and } \\
\text { continued formation } \\
\text { level (PRONATEC) }\end{array}$ & $\begin{array}{l}\text { Non validation of new units of private HEI to } \\
\text { PRONATEC, conditioned by the General Index of } \\
\text { Evaluated Courses of the institution (ICG) equal } \\
\text { or superior to score } 3 \text {. }\end{array}$ \\
\hline
\end{tabular}

Source: Brazilian Law and Government regulation - MEC/INEP

Thus, the purpose of this research is to understand how a private HEI in Brazil can be able to conciliate providing high quality courses for the students with the value creation for the owners/investors, such as economic return which meets up to the expectations. As his primary goal, the Dean needs to run the educational portfolio management to lead his/her internal operations activities.

In order to deliver consistently superior performance, the resources and skills managed by the organizations have to provide alternatives that can present themselves as value sources and flows (BONTIS, 2002). Thus, this study leads mainly through a scenario twisted by the concern upon the efficiency of the development of course offers, which leads to the perception of a high value added, focused on capabilities. Having those courses depending on exclusive learning curves, with just few chances to face substitute competition, and under full ownership of the HEI, becoming the first step on the path to market leadership.

Since the Deans of a HEI are those who handle everyday operations, it's legit to give them a representative position on the identification of factors that influence both the performance on daily basis and the long-range value creation. Then we adopt a framework of value creation related to the management of intellectual capital and intangible actives, to identify and discuss the perception of these subjects concerning the HEI's vectors of performance, and develop a descriptive study to categorize groups and point out relationships of mutual dependency among theoretical constructions.

The concept of value creation in an organization can be taking into account by the dimensions of the Financial Capital joined by the Intellectual Capital tripod (M'PHERSON, PIKE 2001): the Human Capital, the Relational Capital and the Structural Capital.

\section{Private Higher Education Industry in Brazil}

Soares (2002) claims that the main changes on the higher education segment in Brazil come from the decade of 1990, with the beginning of an increasing phase concerning enrollments, as well as the laws regulating higher education by LDB (Laws of Directives and Basis of the National Education) becoming more flexible in 1996.

According to Monteiro e Braga (2004), the education panorama in Brazil has presented relevant changes on the first government of President Fernando Henrique Cardoso (1995-1998), when the former principal of UNICAMP, Paulo Renato Souza, has played the function of the State Ministry of Education. At that time the offer growth of the private segment of higher education has started (INEP 2013), attempting to attend the demand by not enrolled students, especially from low-income classes. 
In order to monitor that growth, the government has adopted, as one of its control tools, the National Exam of Courses, with the purpose to follow the educational performance of the undergraduate students, on an assessment that took place at the end of each course (Federal Law 9131, of 1995).

During the first government of President Lula da Silva (2003-2007), such policy of amplifying vacancies in the higher education, was not only continued but also increased, through several programs of public financing (PROUNI and FIES) targeting low incoming students. Such widening is also justified by the beginning of distance courses at this same period of time (BRASIL, 2004).

The results provided by INEP (2013) over the higher education in Brazil, reveal that from 2001 to 2010, the enhancing of access to higher education was around 110.1\%, (INEP, 2013). In 2012, the private HEI in Brazil held $67.7 \%$ of the graduation courses, while the public universities had 32.3\%. In 2012, Brazil had 2.112 private HEI (INEP, 2013).

The National Exam of courses was transformed into National Exam of Higher Education Performance (ENADE), which, on a wider approach, evaluated not only the students' performance in a test, but also through other metrics (BRASIL, 2004), such as level of satisfaction with the offered conditions by the graduates and percentage of professors with title of MSc and PhD.

The HEI's courses which did not reach a satisfactory performance on ENADE, had their vacancies reduced, or were even closed until the visit of a committee of evaluators representing the Ministry of Education (MEC). This committee would authorize the re-opening of vacancies, as soon as several enhancing concrete actions had been took in the courses with previous bad evaluations.

Thus, the private HEI must not only be concerned about the financial aspect. A minimum reference of educational quality is a need on the standards demanded by the regulation entity, to protect the progress of the provided courses, main source of revenue for the HEI and for the value creation for the owners (family or investors).

\section{The Brazilian Private HEI's Strategic Thinking}

The increased number of private HEI in Brazil presented by INEP (2013) between 2001 and 2010, has also enhanced the competition among them. In this same period, occurs an improvement on the acquisitions and fusions on the education industry, which led to the empowering of truly conglomerates (CM CONSULTORIA, 2012).

Carvalho (2013) points the HEI management phenomenon from a wider perspective, rooted on the global context. For the author, the transformations upon the private education industry come from assuming the interests of the international capital, and not only as a local market matter, simply based on traditional competitors rivalry (CARVALHO, 2013). That's how she denotes out three different paths for obtaining better results:

i) Professionalization of the education industry incumbents, comprehending recruiting for principals with the necessary skills to mediate the relationship between owners and entity, extinguishing the usual practices observed in family businesses;

ii) Transformation of universities and colleges in conglomerates or holdings;

iii) Sell an "optimal" share of control of the HEI to foreign investors' capital.

Those great education groups settled strategies aiming the scale economy, optimizing the administrative and pedagogical structure through monitoring inner and outer environments, as: current and potential students, laws regarding higher education and governmental entities, information over future scenario, quality of professors, competition in the industry, board of directors, finances, among others.

Casartelli et al (2010) highlight the importance of the strategical intelligence in HEI. The author approaches the need of this tool in order to reach the aimed results, whose goals would be set from the study of scenario and proper interpretation.

For Janissek-Muniz, Lesca e Freitas (2006), the strategical intelligence allows to carry essential information to the proper creation and implementation of the strategy, optimizing efforts and resources of the organization.

Under the perspective of public policies for higher education, Silva Junior et al (2014) introduce some of the strategies used by private HEI in the creation of the Institutional Development Plan (PDI), which mainly regards the alignment with the owners.

Meyer Jr, Pascucci e Mangolin (2012) observed, from the observed universities, that the strategy doesn't have a satisfactory result when the integration of the strategic budget planning is not consistent. 


\section{Perceptions of Intellectual Capital and Value Creation in the HEI}

Besides the strategy practiced by the private HEI, what shall keep it will be the value perceived by their customers. This context of provided value proposition constitutes a dynamic benefit-cost relationship. The benefits will be understood as emotional and functional, while the costs, as money, time, energy and psychological. "The higher the value perceived by the client, the biggest shall be his tendency to acquire the product or service" (DIAS, 2006, p. 361).

According to the Service Dominant Logic (SDL), "the customer is always a co-author of the value" (PAYNE, STORBACKA, FROW 2008, p. 84), and for Prahalad e Ramaswamy (2003) the value comes from a specific time and space in an individual experience".

It's suitable to bold the duality on who is truly the HEI's customer. For Holanda Jr. (2006) the debate over the issue must consider the external and internal environments described by Sirvanci (1996). In the external environment, the customer would be the society, while in the internal the student would be the customer. Therefore, depending on the several roles a student can perform inside the HEI's processes, they might be classified as customer or not, even changing their perception over value.

Despite of the fact that the conception of value has several interpretations, the study carried by M'Pherson, e Pike (2001) classifies the market value for public companies as the integration between the accounting value and the intangible value.

The accounting value, or Financial Capital, consists the adding of the physical capital (stocks, factory, devices and assets) plus the monetary capital (investments, money, incomings, receivables).

As for the intangible value (Intellectual Capital), it holds almost all the assets not properly measured by the organization. Edvinson and Malone (1998) build a metaphor of the Intellectual Capital (IC) with the roots of a tree. According to the authors, the described in the annual reports of the financial demonstrations and supplementary brochures, among other documents, shows the trunk, branches and leaves of the tree. The roots of the tree are the Intellectual Capital drivers of the organization, starting point for the value creation.

Many authors assume that the Intellectual Capital can be observed under three dimensions: Human Capital (HC), Structural Capital (SC) and Relational Capital (RC).

The Human Capital consists in the individual or group effort of employees, while issues as physical infrastructure, managerial philosophy and management of processes, not forgetting its ICT capabilities, build the Structural Capital. The Relational Capital considers the relationship between the organization with its environments, internal and external, including customers, suppliers, government and other organizations. (KAPLAN; NORTON, 1997; STEWART, 1998; BONTIS, 1999; BONTIS et al., 2000; IADE 2003; GONZÁLEZ; SALLERO, 2010).

This description of market value comes from the experience of the report "Visualizing Intellectual Capital", a side supply to the annual report of the Swedish insurance company Skandia in 1994 (STEWART,1998). It was a landmark for the study and presentation of the reports of IC, by going beyond the traditional models of accounting demonstrations.

Some of the studies attempting to identify the value in HEI hold as a reference the Intellectual Capital (SÁNCHEZ-TORRES, 2010; SILVA JÚNIOR, 2009; GARCIA ET AL, 2012). The researches in Brazil and worldwide consider the $\mathrm{HC}, \mathrm{SC}$ and RC dimensions of the Intellectual Capital, although they make it clear that one is not unlinked from the other. There is an interdependency relationship among the IC dimensions (MARTOS, FERNANDEZ-JARDON \& FIGUEROA, 2008; NAZARI et al, 2009; LIMA \& CARMONA, 2011).

Nevertheless, there are differences concerning the drivers identified in each dimension. Moura et al. (2005) made a research with Deans of the HEI about the management of Human Capital, based on the qualification (training), support to degrees achievements, career plan and fellowship for R \& D.

Awad (2010) applied surveys in a government university, to verify the opinion of professors, employees and students about the indexes of Intellectual Capital, considering the patterns settled by Maurer (2008). In order to validate the model of assessment on Intellectual Capital in graduate programs, Peroba (2013) made a quantitative research with coordinators and professors. Machado (2008) studied Portuguese and Spanish universities in order to identify and measure the Intellectual Capital by professors. 


\section{Research Design}

We developed this study based on literature review and descriptive research. The review aimed to rescue some contributions published over the past years about HEI management and the foundations of IC. As for the descriptive research, according to Vergara (2009), it shows characteristics of a given population or a given phenomenon. The sample was accessibility type, since the observed HEI supported the application of the survey to its Deans.

For being the ones in charge for the operation of the strategy planned by the board directors, there is reasoning for the Deans to be the proper responsible ones to present their manifestations about the factors that surround the question in the research, which consists in identifying elements that can lead to the value creation in the private HEI.

Therefore, in order to have a further and more consistent discussion over the matter, this study is mainly concentrated on the discussion of the following hypothesis, to contribute to the reach of the purpose in this research:

- $\mathrm{H}_{0,1:}$ There are no distinct clusters of Deans' perceptions over the dimensions that contribute to create value in a HEI.

- $\mathrm{H}_{0,2}$ : There are no differences among the opinions of the Deans of the HEI about the dimensions of value creation.

- $\mathrm{H}_{0,3}$ : There are no relations of interdependence among the HEI's dimensions of value creation.

The survey covered a population composed by 228 Deans of one Brazilian private HEI. Those subjects provided 97 answers.

The observed HEI is an educational group founded in 1971, based in Rio de Janeiro. Is among the largest educational groups in Brazil with a total enrollment of 437.4 thousand students, of whom 83 thousand are from distance/blended learning. It maintains the management of seven University Centers, 36 Colleges, a full University and 163 active e-learning centers, having 85 campi.

It is a public corporation, listed at the Brazilian stock market, with revenues of US\$ 904.24 million and EBITDA of US\$ 200.51 million. The HEI carries out a professional style of management, with intensive use of the Balanced Scorecard for the monitoring of the goals.

The choice of the Deans considered their authority and responsibility in this HEI for beyond the support staff described by Mintzberg (1995). In this HEI, Deans also have the duty to lead the operational center, composed by coordinators and professors from different courses - Technostructure - and make the coupling with the Strategic Apex, playing a relevant role on the ideology institutionalization (MINTZBERG, 1995).

"The dean shall have primary responsibility for representing the views of the college faculty to all groups and persons external to the college, particularly to the central administration of the university. The dean shall be responsible for the administration and efficient conduct of the educational program of the college and for integrating the plans of the college with those of the university. The dean shall enforce the policies and regulations adopted by the Board of Trustees, the Office of the President, the Faculty Senate, and the college faculty. In addition, the dean's efforts shall be guided by the specific responsibilities contained in the job description for the Dean of the College of Education and Human Development." (LOUISVILLE, 2016)

As chief academic officer of the college, the Dean is responsible for the academic, personnel, financial, and administrative affairs of the college. The Dean is also responsible for communicating the vision and goals of the College to community and professional constituencies and seeking public and private funds to support the goals of the college.

The survey was developed based on the dimensions and drivers of the Intellectual Capital (Relational, Human, Structural - plus the Financial Capital). The study adopted the Likert scale from one to six (Total Disagreement to Total Agreement), in order to avoid individuals to have a neutral position about any given IC driver.

\section{Constitutive and Operational Dimension of the IC Value Drivers}

The choice over the dimensions of the value creation for the survey application had as criteria the experience from previous studies concerning Intellectual Capital in HEI, as well as metrics coherent to the financial perspective of the Balanced Scorecard (Kaplan \& Norton, 1992) presenting results from discussions taken before (Exhibit 2).

In order to express each dimension of value creation according to the theoretical landmarks, we compute constructs from arithmetic averages with the scores of each set of six previously selected drivers and whose propositions in the survey were pretested. 
Exhibit 2. Dimensions and drivers of HEI's value creation

\begin{tabular}{|c|c|c|}
\hline IC Dimensions & BSC Perspectives & Drivers \\
\hline Relational Capital & Customers - Market & $\begin{array}{ll}\text { - } & \text { Social and environmental responsibility } \\
\text { - } & \text { Institutional image and identity } \\
\text { - } & \text { Offers based on the student as customer } \\
\text { - } & \text { Alumni employability actions } \\
\text { - } & \text { International research centers partnerships } \\
\text { - } & \text { Covenants with organizations \& associations } \\
\end{array}$ \\
\hline Human Capital & Learning and Growing & $\begin{array}{ll}\text { - } & \text { Lecturers' distinctive role } \\
\text { - } & \text { Faculty's scientific production orientation } \\
\text { - } & \text { Clerical staff's performance } \\
\text { - } & \text { Professional workforce's knowledge } \\
\text { - } & \text { Qualification and merit based compensation } \\
\text { - } & \text { Coordinator's entrepreneurial mindset } \\
\end{array}$ \\
\hline Structural Capital & Internal Processes & $\begin{array}{l}\text { - Institutional Pedagogical Project decision based } \\
\text { - Strategy and structure alignment } \\
\text { - } \quad \text { Processes \& Performance based management } \\
\text { - Academic routines' ICT platform } \\
\text { - } \quad \text { MIS' effectiveness } \\
\text { - } \quad \text { Infrastructure and premises conceptualization }\end{array}$ \\
\hline Financial Capital & Economic - Financial & $\begin{array}{l}\text { - } \text { Revenue scanning } \\
\text { - } \text { Effective cost control } \\
\text { - } \quad \text { Cash flow balance } \\
\text { - } \quad \text { Resourgeting compliance } \\
\text { - Investment maturity }\end{array}$ \\
\hline
\end{tabular}

Source: Adapted by the Authors

\section{Findings}

The initial steps after the application of the survey aim to identify the distribution pattern of the subjects' responses in relation to the presence of each value creation driver in the studied HEI, with no need to exclude outliers. The data organization take in to account the agreement or disagreement positions of the subjects, with not revealed scores to represent magnitudes. The answers were consolidated in three strata (I disagree totally or very strongly, I disagree or agree in part, I agree very or totally) and a general agreement index was computed (Table 1).

Table 1 shows the drivers already categorized according to the theoretical Intellectual Capital management dimensions of value creation, and it is possible to identify the non-fulfillment of conditions of adherence to the log-normal distribution - in view of this, some of the hypothesis tests were computed based on non-parametric procedures. From the point of view of the sample as a whole, the items with the lowest contribution to value generation in the IES are infrastructure and premises conceptualization (SC), international research centers partnerships (RC), academic routines' ICT platform (SC) and budgeting compliance (FC).

The reliability test aims for the extension in which a single factor or a construct of factors is consistent to what shall be measured (Hair et al, 2005). According to Malhotra, (2006) the values above 0.6 have robust support for empirical-theoretical discussions. Table 2 shows the Cronbach's Alpha results for the drivers of IC value creation.

According to Hair (2005), reliability is considered a point that bounds until where "a construct measures and must measure". The reliability of the constructs reinforces the literature review concerning the Financial and Intellectual Capital as a source of value creation. 
Table 1. Observed HEI Dean's agreement distribution on the existence of the IC value creation drivers

\begin{tabular}{|c|c|c|c|c|}
\hline Dimension/Drivers & $\begin{array}{c}\text { Totally or } \\
\text { very much } \\
\text { Disagreement } \\
\end{array}$ & $\begin{array}{c}\text { Low } \\
\text { Disagree } \\
\text { Low Agree } \\
\end{array}$ & $\begin{array}{c}\text { Totally or } \\
\text { very much } \\
\text { Agreement } \\
\end{array}$ & $\begin{array}{c}\text { General } \\
\text { Agreement } \\
\text { Index (*) } \\
\end{array}$ \\
\hline \multicolumn{5}{|l|}{ Relational Capital } \\
\hline Social and environmental responsibility & 3,09 & 37,11 & 59,79 & 92,78 \\
\hline Institutional image and identity & 1,03 & 43,30 & 55,67 & 89,69 \\
\hline Offers based on the student as customer & 1,03 & 29,90 & 69,07 & 93,81 \\
\hline Alumni employability actions & 1,03 & 38,14 & 60,82 & 94,85 \\
\hline International research centers partnerships & 1,03 & 46,39 & 52,58 & 83,51 \\
\hline Covenants with organizations \& associations & 2,06 & 34,02 & 63,92 & 94,85 \\
\hline \multicolumn{5}{|l|}{ Human Capital } \\
\hline Lecturers' distinctive role & - & 35,05 & 64,95 & 93,81 \\
\hline Faculty's scientific production orientation & - & 31,96 & 68,04 & 94,85 \\
\hline Clerical staff's performance & 2,06 & 29,90 & 68,04 & 94,85 \\
\hline Professional workforce's knowledge & - & 35,05 & 64,95 & 94,85 \\
\hline Qualification and merit based compensation & 2,06 & 40,21 & 57,73 & 92,78 \\
\hline Coordinator's entrepreneurial mindset & 2,06 & 40,21 & 57,73 & 91,75 \\
\hline \multicolumn{5}{|l|}{ Structural Capital } \\
\hline Institutional Pedagogical Project decision based & 1,03 & 43,30 & 55,67 & 94,85 \\
\hline Strategy and structure alignment & 2,06 & 22,68 & 75,26 & 96,91 \\
\hline Processes \& Performance based management & 2,06 & 31,96 & 65,98 & 93,81 \\
\hline Academic routines' ICT platform & 5,15 & 39,18 & 55,67 & 88,66 \\
\hline MIS' effectiveness & 3,09 & 40,21 & 56,70 & 91,75 \\
\hline Infrastructure and premises conceptualization & 9,28 & 62,89 & 27,84 & 79,38 \\
\hline \multicolumn{5}{|l|}{ Financial Capital } \\
\hline Revenue scanning & 1,03 & 6,19 & 92,78 & 97,94 \\
\hline Effective cost control & 1,03 & 13,40 & 85,57 & 97,94 \\
\hline Cash flow balance & - & 19,59 & 80,41 & 98,97 \\
\hline Budgeting compliance & 5,15 & 42,27 & 52,58 & 87,63 \\
\hline Resources decentralization for business units & 4,12 & 50,52 & 45,36 & 90,72 \\
\hline Investment maturity & 1,03 & 37,11 & 61,86 & 92,78 \\
\hline
\end{tabular}

97 cases. (*) "Low" + "Very Much" + "Totally Agreement"

Source: Authors' research (2014)

Table 2. Reliability of the dimensions / constructs of value creation

\begin{tabular}{lcc}
\hline Dimensions & Number of items & Cronbach's Alpha \\
\hline Relational Capital & 6 & 0.863 \\
Human Capital & 6 & 0.794 \\
Structural Capital & 6 & 0.857 \\
Intellectual Capital & 3 & 0.891 \\
Financial Capital & 6 & 0.710 \\
Value Creation & 2 & 0.743 \\
\hline
\end{tabular}

Source: Authors' research (2014) 
With the purpose of clustering or classifying a given group of subjects, setting as a similarities and dissimilarities parameter the averages of each dimension based on answers collected for the drivers, we used the test of hierarchical clustering, identifying graphically — dendogram - three hierarchical clusters.

To confirm the existence of hierarchical clustering, the analysis of variance (ANOVA) and multi variated analysis of variance (MANOVA) were implemented trough the SPSS v. 20 software. By computing at the same time the four clustering constructs, was possible to affirm that the clusters are significant different ( $p$ value $<0,000$; Table 3): 19 Deans in the group "Academic", 17 Deans in the "Corporative" and 61 in the "Operative".

Table 3. Clustering validity tests

Source: Authors' research (2014)

\begin{tabular}{lcc}
\hline & F & Sig \\
\hline ANOVA & & \\
\hline Relational Capital & 66.652 & 0.000 \\
Human Capital & 58.000 & 0.000 \\
Structural Capital & 67.884 & 0.000 \\
Financial Capital & 71.287 & 0.000 \\
\hline MANOVA & & \\
\hline Pillais test & 17.12 & 0.000 \\
Wilks test & 31.09 & 0.000 \\
\hline
\end{tabular}

The sample was generated by means of an electronic survey made available through the Google Docs platform, obeying a response period of 45 days, between June and August 2014. No adherence test was performed between characteristics of the sample and the population, reinforcing the need to face this research as a descriptive study, not aiming at generalizations.

Table 4 presents the demographic data surveyed, with the effects of grouping the observations into clusters. The highlights are: (i) formal education at the level of specialization (Lato Senso graduate); (ii) enrolment of the subjects in internal training programs promoted by HEI seeking the development of management skills (with emphasis on medium duration); (iii) working time at the institution (pointing understanding the organizational culture).

Table 4. Deans' sample demographics

\begin{tabular}{llcccc}
\hline & & \multicolumn{3}{c}{ Clusters } & \multirow{2}{*}{ Sample } \\
\cline { 3 - 5 } & & Academic & Corporative & Operative & \\
\hline Subjects \# & Non declare & 5.15 & 17 & 61 & 97 \\
\hline & High School & 1.03 & - & 16.49 & 25.77 \\
Formal Education \% & BSc & 1.03 & 2.06 & - & 1.03 \\
(of the sample) & Specialist & 12.37 & 11.34 & 37.11 & 6.19 \\
& MSc & - & - & 1.03 & 60.82 \\
& PhD & - & - & 5.15 & 5.15 \\
\hline HEI HR Development & Non participate & 1.03 & 4.12 & 11.34 & 16.49 \\
internal enrolment \% & Extension & 15.46 & 9.28 & 36.08 & 60.82 \\
(of the sample) & Specialization & 3.09 & 4.12 & 15.46 & 22.68 \\
\hline Gender \% (of the & Male & 10.31 & 10.31 & 39.18 & 59.79 \\
sample) & Female & 9.28 & 7.22 & 23.71 & 40.21 \\
\hline Average age (years) & & 37.53 & 41.41 & 40.08 & 59.65 \\
\hline Average working in HEI (years) & 8.68 & 12.88 & 10.46 & 9.30 \\
\hline Average working at the HEI (years) & 6.68 & 10.12 & 7.95 & 8.08 \\
\hline
\end{tabular}

Source: Authors' research (2014) 
When we focus on the hierarchical clusters, it is possible to perceive some discrepancies that may contribute to the formation of managerial thinking and which are portrayed in the clustering results: (i) 18 out of 19 managers participated in training in the "Academic" cluster (almost 100\%); (ii) in the group "Corporative", 13 in 17 also participated (more than 75\%); although 50 out of 61 "Operative" managers took part in T \& D efforts, most (70\%) did so in the medium-term course.

\section{Discussion}

Through the $\mathrm{H}_{0,1}$ testing based on hierarchical clustering, three groups were identified, with peculiar sample characteristics here called "Corporative", "Operative" and "Academic" (to be discussed furthermore ahead). The choice of using metaphors follows the perspective of Morgan (1980), whose use of names for each cluster helps to visualize them as instruments for the organizational research.

It's important to emphasize that this categorization is not anyhow related to the organizational positions plan used by the HEI; instead refers to the ex post profile of the subjects, based on answers in the survey.

Using the average of the listed drivers as construct metrics for each dimensions of the analytical framework, based on the ANOVA / MANOVA, has been possible to identify statistical significant differences for each cluster among the three clusters hierarchical groups. Thus, the first null hypothesis has had rejected in favor of the alternative hypothesis, been reasonable to clustering the Deans according to their opinions concerning the IC HEI's dimensions of value creation.

By analyzing the dimensions in each cluster, according to the Deans, the Financial Capital (4.973 average) is the one of more expressive value for the HEI. That result could be expected, considering the nature of this HEI as a corporation controlled by an investor group. However, regarding the dimensions of the Intellectual Capital, the differences among the groups become present (Table 5).

At the other extreme, we found the Structural Capital dimension as the one that faces, as a whole, the great criticism (4.636 average) and the lowest convergence ( 0.761 standard deviation), also expected since the Deans operate across the country under different conditions and resources.

Considering the magnitudes of the average scores of the dimensions, we found statistical support to partially reject $\mathrm{H}_{0,2}$, in favor of the alternative hypothesis - so there are differences about the Deans' perspectives on the value creation of the observed HEI: (i) the Deans' perceptions point Financial Capital more intense than the other three dimensions, with the $\mathrm{p}$ value $<0.05$; (ii) Human Capital is more intense than Structural Capital, with $\mathrm{p}$ value $<0.05$; (iii) Relational Capital is more intense than Structural Capital, $\mathrm{p}$ value $<0.10$; and (iv) there is no statistical support for the difference between Relational Capital and Human Capital.

\section{1 "Corporative Deans"}

The "Corporative" Deans' group represents $17.53 \%$ of the total of the subjects of the sample. Those Deans totally agree in most of the drivers asked in the survey, presenting among each other a low dispersion in the answers. This group seems aligned with the major corporate orientations of the HEI in which they perform.

However, the excessive generosity on the scores averages given must be seen with reservations: this group has professionals with the greats industry and HEI working years and are middle age persons, so could stay in the presence of some behavioral pressure - mainly under external M\&A plus unemployment and internal operational efficiency goal seeking scenario.

In this group, the most scored dimension is the Financial Capital (Table 5 and Exhibit 3). For the "Corporative Deans", extending the $\mathrm{H}_{0,2}$ discussion, we found: (i) Financial Capital more intense than Human Capital and Structural Capital, with the $\mathrm{p}$ value $<0.10$; (ii) Relational Capital is more intense than Human Capital, with $\mathrm{p}$ value $<$ 0.10 ; and (iii) there is no statistical support for other differences among dimensions.

The identification of the student as the customer focus is the starting point to development of the value proposition, moving it trying to achieve academic excellence on scientific production and through strategic alignment.

Since this cluster seems to reproduce the governance orientations, the subjects clearly score in favor of corporative management artifacts that promote performance and value seeking - qualification and merit based compensation, processes and performance based management - and criticize trade-offs that could create local units lacks budgeting compliance, resources decentralization, coordinator's entrepreneurial mindset, clerical staff's performance. 
Table 5. Average importance given by the deans to the dimensions of value creation

\begin{tabular}{|c|c|c|c|c|c|c|}
\hline C & Statistics & $\begin{array}{c}\text { Relational } \\
\text { Capital }\end{array}$ & $\begin{array}{l}\text { Human } \\
\text { Capital }\end{array}$ & $\begin{array}{c}\text { Structural } \\
\text { Capital }\end{array}$ & $\begin{array}{c}\text { Financial } \\
\text { Capital }\end{array}$ & $\begin{array}{c}\text { Intellectual } \\
\text { Capital }\end{array}$ \\
\hline \multirow{7}{*}{ 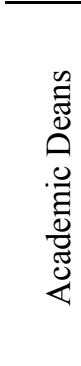 } & $\overline{\mathrm{x}}$ & 3.842 & 3.991 & 3.605 & 4.272 & 3.798 \\
\hline & $\mathrm{s}$ & 0.537 & 0.410 & 0.788 & 0.401 & 0.524 \\
\hline & $\mathrm{N}$ & 19 & 19 & 19 & 19 & 19 \\
\hline & SRT_HC ${ }^{a}$ & 0.119 & & & & \\
\hline & SRT_SC ${ }^{a}$ & 0.091 & 0.001 & & & \\
\hline & SRT_FC ${ }^{a}$ & 0.000 & 0.006 & 0.000 & & \\
\hline & SRT_IC ${ }^{a}$ & 0.893 & 0.055 & 0.005 & 0.000 & \\
\hline \multirow{7}{*}{ 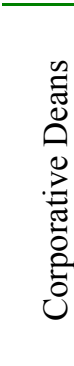 } & $\overline{\mathrm{X}}$ & 5.677 & 5.520 & 5.480 & 5.696 & 5.582 \\
\hline & S & 0.356 & 0.343 & 0.448 & 0.135 & 0.323 \\
\hline & $\mathrm{N}$ & 17 & 17 & 17 & 17 & 17 \\
\hline & SRT_HC ${ }^{a}$ & 0.071 & & & & \\
\hline & SRT_SC ${ }^{a}$ & 0.113 & 0.695 & & & \\
\hline & SRT_FC ${ }^{a}$ & 0.908 & 0.086 & 0.081 & & \\
\hline & SRT_IC ${ }^{a}$ & 0.221 & 0.381 & 0.181 & 0.224 & \\
\hline \multirow{7}{*}{ 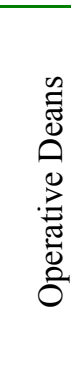 } & $\overline{\mathrm{X}}$ & 4.754 & 4.858 & 4.721 & 4.989 & 4.792 \\
\hline & $\mathrm{S}$ & 0.483 & 0.456 & 0.376 & 0.386 & 0.363 \\
\hline & $\mathrm{N}$ & 61 & 61 & 61 & 61 & 61 \\
\hline & SRT_HC ${ }^{a}$ & 0.072 & & & & \\
\hline & SRT_SC ${ }^{a}$ & 0.491 & 0.010 & & & \\
\hline & $\mathrm{SRT}_{-} \mathrm{FC}^{\mathrm{a}}$ & 0.004 & 0.098 & 0.000 & & \\
\hline & SRT_IC ${ }^{a}$ & 0.362 & 0.091 & 0.057 & 0.001 & \\
\hline \multirow{7}{*}{ 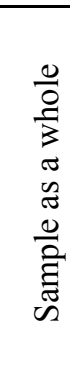 } & $\overline{\mathrm{X}}$ & 4.737 & 4.804 & 4.636 & 4.973 & 4.736 \\
\hline & $\mathrm{S}$ & 0.674 & 0.636 & 0.761 & 0.732 & 0.674 \\
\hline & $\mathrm{N}$ & 97 & 97 & 97 & 97 & 97 \\
\hline & SRT_HC ${ }^{a}$ & 0.170 & & & & \\
\hline & SRT_SC ${ }^{a}$ & 0.074 & 0.002 & & & \\
\hline & SRT_FC ${ }^{a}$ & 0.000 & 0.007 & 0.000 & & \\
\hline & SRT_IC ${ }^{a}$ & 0.977 & 0.061 & 0.007 & 0.000 & \\
\hline \multicolumn{2}{|c|}{ MW_U: A1-A2 ${ }^{b}$} & 0.000 & 0.000 & 0.000 & 0.000 & 0.000 \\
\hline \multicolumn{2}{|c|}{ MW_U: $\mathrm{A} 1-\mathrm{A} 3^{\mathrm{b}}$} & 0,000 & 0.000 & 0.000 & 0.000 & 0.000 \\
\hline \multicolumn{2}{|c|}{ MW_U: A2 - A $3^{b}$} & 0.000 & 0.000 & 0.000 & 0.000 & 0.000 \\
\hline
\end{tabular}

${ }^{a}$ Comparisons among the indexes if the cluster, based on the SRT Signed-Rank Test of Wilcoxon (side by side samples)

${ }^{\mathrm{b}}$ Comparisons among the index in each cluster based on the U Test by Mann-Whitney

Bold $p$ values are $<0,05$; italic and bold $p$ values are $<0,10$

Source: the authors 
Exhibit 3. "Corporative Deans" perspectives on value creation

\begin{tabular}{|c|c|c|c|}
\hline & Dimensions & Drivers adding more value & Drivers adding less value \\
\hline $1^{\text {st }}$ important & Financial Capital & $\begin{array}{l}\text { - } \quad \text { Revenue scanning } \\
\text { - } \quad \text { Cash flow balance }\end{array}$ & $\begin{array}{ll}- & \text { Budgeting compliance } \\
- & \text { Resources } \\
& \text { decentralization } \\
\end{array}$ \\
\hline $2^{\text {nd }}$ important & Relational Capital & $\begin{array}{ll}- & \text { Offers based on the } \\
\text { student as customer } \\
\text { - } & \text { Social and } \\
\text { environmental } \\
\text { responsibility }\end{array}$ & 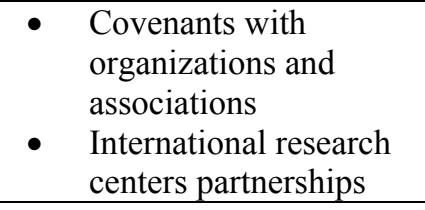 \\
\hline $3^{\text {rd }}$ important & Human Capital & $\begin{array}{ll}\text { - } & \text { Faculty's scientific } \\
\text { production } \\
\text { - } \\
\text { Qualification and merit } \\
\text { based compensation }\end{array}$ & $\begin{array}{ll} & \text { Clerical staff's } \\
& \text { performance } \\
- & \text { Coordinator's } \\
& \text { entrepreneurial mindset } \\
\end{array}$ \\
\hline $4^{\text {th }}$ important & Structural Capital & $\begin{array}{ll}\text { - } & \text { Strategy and structure } \\
\text { alignment } \\
\text { - } & \text { Processes and } \\
\text { performance based } \\
\text { management }\end{array}$ & $\begin{array}{ll}\text { - } & \text { Academic routine's ICT } \\
\text { platform } \\
\text { - } \\
\text { Infrastructure and } \\
\text { premises } \\
\text { conceptualization } \\
\end{array}$ \\
\hline
\end{tabular}

Source: Authors' research (2014)

\section{2 "Operative" Deans}

The cluster of the Operative Deans holds $62.89 \%$ of the total participants of the research. This group recons elements that might generate value by the HEI in which they perform, as much as they are punctual in the identification of drivers the HEI will need to manage in a better way. The upper management of the HEI must be aware of this group, since it holds a considerable part of the sample representation (Exhibit 4).

Despite of having quite similar score averages to the Corporative cluster, these Deans prior the "modus operandi" of the HEI, with special attention to the impacts of the back-office activities and the campus maintenance. The Financial Capital is the main dimension for the value creation, this being the group with the highest score average regarding the criticism above decentralization the operational resources - compatible with a focus more on the local than on the corporation.

As for the Human Capital, these Deans value the performance of clerical employees as the main driver of value creation, some way incoherent with the Human Resources steering of the HEI, facing the dominant logic of operational efficiency, but, again, explained based on the local focus.

Exhibit 4. "Operative Deans" perspectives on value creation

\begin{tabular}{|c|c|c|c|}
\hline & Dimensions & Drivers adding more value & Drivers adding less value \\
\hline $1^{\text {st }}$ important & Financial Capital & $\begin{array}{ll}\text { - Revenue scanning } \\
\text { - }\end{array}$ & $\begin{array}{l}\text { - Resources decentralization } \\
\text { - Budgeting compliance }\end{array}$ \\
\hline $2^{\text {nd }}$ important & Human Capital & $\begin{array}{ll}- & \text { Clerical staff's } \\
& \text { performance } \\
\text { - } & \text { Lecturer's distinctive } \\
& \text { role } \\
\end{array}$ & $\begin{array}{ll}- & \text { Coordinator's } \\
\text { entrepreneurial mindset } \\
\text { - } & \text { Qualification and merit } \\
\text { based compensation }\end{array}$ \\
\hline $3^{\text {rd }}$ important & Relational Capital & $\begin{array}{ll}- & \text { Offers based on the } \\
\text { student as customer } \\
\text { - } \\
\text { Alumni employability } \\
\text { actions }\end{array}$ & $\begin{array}{ll}- & \text { International research } \\
\text { centers partnerships } \\
\text { - } & \text { Social and environmental } \\
\text { responsibility }\end{array}$ \\
\hline $4^{\text {th }}$ important & Structural Capital & 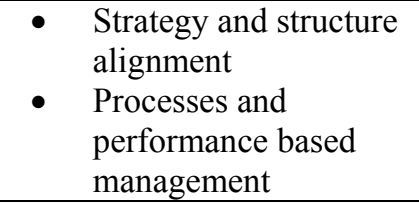 & $\begin{array}{l}\text { - Infrastructure and premises } \\
\text { conceptualization } \\
\text { - Institutional Pedagogical } \\
\text { Project decision based }\end{array}$ \\
\hline
\end{tabular}

Source: Authors' research (2014) 
As a matter of local versus corporation clash, the institution as whole is in some way criticized, since this cluster did not score Institutional Pedagogical Project (IPP) based decision as an important driver for value creation in the Structural Capital. The IPP would be the presentation of the institution for the stakeholders.

Operatives value the identification of the student as customer as the main driver of the Relational Capital, sustained through employability actions supported both for the HEI and the labor market. The concern with the internal environment, on the accomplishment of the routines, appears to gain more value for these Deans than the articulation of the HEI with the society.

We found, testing extended $\mathrm{H}_{0,2}$ for the "Operative Deans": (i) Financial Capital is more intense than RC and SC, with the $p$ value $<0.05$; (ii) Financial Capital more intense than $\mathrm{HC}$, with the $\mathrm{p}$ value $<0.10$; (iii) Human Capital is more intense than Structural Capital, with $\mathrm{p}$ value $<0.05$; (iv) Human Capital is great than Relational Capital, $\mathrm{p}$ value $<0.10$; and (v) there is no statistical support for other differences based on the Deans' perceptions.

\section{3 "Academic" Deans}

In a general way, the "Academics" are more severe and critical on the identification of drivers that might create value to the HEI (Exhibit 5). The cluster represents $19.59 \%$ of the total participants. They are stricter in the agreement of the required drivers in the survey. One shall not make the mistake to classify this group as pessimist or not aligned with the strategy of the HEI. Their presence is fundamental for the praxis reflection of the actions taken, being able to foresee adversative scenarios unpredicted by their peers.

On the "Academic Deans", we found testing $\mathrm{H}_{0,2}$ : (i) Financial Capital more intense than the other three dimensions, with the $\mathrm{p}$ value $<0.05$; Human Capital is more intense than Structural Capital, with $\mathrm{p}$ value $<0.05$; (iii) Relational Capital is more intense than Structural Capital, $\mathrm{p}$ value $<0.10$; and (iv) there is no statistical support for the difference between Relational Capital and Human Capital.

Exhibit 5. "Academic Deans" perspectives on value creation

\begin{tabular}{|c|c|c|c|}
\hline & Dimensions & Drivers adding more value & Drivers adding less value \\
\hline $1^{\text {st }}$ important & Financial Capital & $\begin{array}{ll}\text { - } & \text { Revenue scanning } \\
\text { - } & \text { Cash flow balance } \\
\end{array}$ & $\begin{array}{ll}\text { - } & \text { Budgeting compliance } \\
\text { - } & \text { Investment maturity }\end{array}$ \\
\hline $2^{\text {nd }}$ important & Human Capital & $\begin{array}{ll}\text { - } & \text { Faculty's scientific } \\
\text { production orientation } \\
\text { - } & \text { Professional } \\
& \text { workforce's knowledge }\end{array}$ & $\begin{array}{l}\text { - } \begin{array}{l}\text { Qualification and merit } \\
\text { based compensation }\end{array} \\
\text { - } \begin{array}{l}\text { Coordinator's } \\
\text { entrepreneurial mindset }\end{array}\end{array}$ \\
\hline $3^{\text {rd }}$ important & Relational Capital & $\begin{array}{ll}- & \begin{array}{l}\text { Covenants with } \\
\text { organizations \& } \\
\text { associations }\end{array} \\
\text { - } & \text { Offers based on the } \\
\text { student as customer }\end{array}$ & $\begin{array}{ll}- & \text { Social and } \\
\text { environmental } \\
\text { responsibility } \\
\text { - } & \text { Institutional image and } \\
& \text { identity }\end{array}$ \\
\hline $4^{\text {th }}$ important & Structural Capital & $\begin{array}{l}\text { - Management based on } \\
\text { mission and values } \\
\text { - Institutional } \\
\text { pedagogical project } \\
\text { alignment }\end{array}$ & $\begin{array}{ll}\text { - } & \text { Infrastructure and } \\
\text { premises } \\
\text { conceptualization } \\
\text { - Academic routines' } \\
\text { ICT platform }\end{array}$ \\
\hline
\end{tabular}

Source: Authors' research (2014)

Comparing "Academics" and "Operatives", the main confrontation regards the Human Capital, in which Academic Deans placed greater emphasis on scientific production and knowledge held by employees. On the other hand, the Operative Deans identified the performance of administrative employees and teaching practice as the major sources of value.

As for the Relational Capital, "Academics" prioritize the capacity of setting covenants with private companies, public administration and class associations: some times, such agreements are set in order to generate positive externality, mostly for the strengthening of the institutional pedagogical projects rather than the image of the HEI. 
This driver is not quite supported by both "Corporatives" and "Operatives", because they have an internal orientation than the Academics.

\subsection{Interdependence among IC Value Creation Dimensions}

By observing the interdependence of values among the different dimensions of value creation, one might perceive in Table 6 that there is a strong relation among then composing the Intellectual Capital. However, when confronting these with the dimension of the Financial Capital, the Rho resultant coefficient is moderate.

Anyway, the third null hypothesis has had rejected, once, according to the perception of the Deans, there are significant correlations $(\mathrm{p}<0.05)$ - strong or moderate - among the four dimensions of value creation. Since we have observed in advance that the sample does not attend normal distribution requisites, we adopt the Spearman's Rho to test interdependence.

Table 6. Interdependence among the dimensions of value creation (Spearman's Rho)

\begin{tabular}{cccc}
\hline $\begin{array}{c}\text { Coefficients of correlation } \\
(\mathbf{N}=\mathbf{9 7})\end{array}$ & $\begin{array}{c}\text { Structural } \\
\text { Capital }\end{array}$ & $\begin{array}{c}\text { Relational } \\
\text { Capital }\end{array}$ & $\begin{array}{c}\text { Financial } \\
\text { Capital }\end{array}$ \\
\hline Human Capital & 0.715 & 0.776 & 0.516 \\
\hline Structural Capital & & 0.721 & 0.616 \\
\hline Relational Capital & & & 0.539 \\
\hline
\end{tabular}

All $\mathrm{p}$ value $<0.01$

Source: the authors.

The results are consistent with the theoretical approaches that propose co-creation of value through simultaneous management of the stocks and flows of the distinctive intangible assets to transform and appropriate then as IC competitive based advantages, typical from the Knowledge Economy.

\section{Final Remarks}

Ritualistic survey answering is a risk to be considered when carrying out quantitative research in a single organization, because power relations can undermine the respondents' spontaneity.

However, it is a necessary way to explore new frameworks in the field of Applied Social Sciences, allowing, through successive applications in different contexts, to normalize the research instrument and to seek future studies with a view to the generalization of concepts and artifacts.

The importance of HEIs in the Knowledge Economy is undeniable. Even in the face of criticism about the need for pedagogical reformulations, it is still the main trajectory of vocational training for various professions and occupations.

In the case of developing economies, such as Brazil, the HEIs play an additional role for integrating new entrants into the labor market, especially those of the less affluent classes.

We identified a central issue in the HEI's industry in Brazil, which is the arrival of new players in the form of large international groups of investors. These come in search of market inefficiencies to be solved via their world's learning curve, but, as some say, Brazil is not for amateurs (ROSA, 2006) and the value creation can't be perceived as a mere matter of chance in an unknown environment.

Thus, the professionalization of HEI management teams has become more of a survival issue, but a way of dealing with a new industry configuration.

For HEIs still under family management, professionalization is also a way to seek out new associates who will provide new features and scalability.

Thus, broadening the understanding of what has been going on in managers' mental models of performance and value creation has become an imperative for the establishment of sustainable competitive advantages.

In the case studied, we confronted the Deans' perception of a private capital HEI with some theoretical drivers of value creation related to the approach to the management of Intellectual Capital and Intangible Assets, with the synthesis presented in the Exhibit 6. 
The protocol adopted allowed to categorize the perception of the Deans into three clusters and confirms assumptions of co-creation of value from the dimensions of the IC and respective drivers.

Exhibit 6. Protocol summary

\begin{tabular}{lccc}
\hline Protocol & Test & Result & Significance \\
\hline Design & Cronbach's Alpha & $\begin{array}{c}\text { Robust reliability of all the constructs based on simple } \\
\text { average: RC, HC, SC, FC, IC and Value Creation }\end{array}$ & $\alpha>0,71$ \\
\hline $\mathrm{H}_{0,1}$ & ANOVA / MANOVA & $\begin{array}{c}\text { Rejected, in favor of the existence of three different } \\
\text { hierarchical clusters }\end{array}$ & $\mathrm{p}<0,01$ \\
\hline $\mathrm{H}_{0,2}$ & $\begin{array}{c}\text { SRT of Wilcoxon / } \\
\text { U by Mann-Whitney }\end{array}$ & $\begin{array}{c}\text { Partially rejected since there is no support to validate } \\
\text { sample as a whole differences between RC and HC }\end{array}$ & $\mathrm{p}<0,10$ \\
\hline $\mathrm{H}_{0,3}$ & Spearman 's Rho & $\begin{array}{c}\text { Rejected, in favor of the existence of IC value creation } \\
\text { dimensions interdependence }\end{array}$ & $\mathrm{P}<0,01$ \\
\hline
\end{tabular}

Source: the authors

It's agreed for the three groups of Deans of this HEI that the Financial Capital plays a spotlight role as a value dimension. In fact, a strategy that values the financial sustainability must be in harmony with the strategies of revenue monitoring and cost control. On the other hand, the clusters of Deans showed different results about the dimension that was most valued in the Intellectual Capital of their HEI.

Considering the Structural Capital, it's the dimension with the lowest perception of value. The opinion of all groups of Deans of the HEI agrees that its "infrastructure and premises conceptualization" presents little value concerning the other drivers, which might suggest a study over the convergence of this observation along with the level of satisfaction of students with the classroom and other facilities conditions offered by this HEI.

Another point that deserves attention is the importance of the "coordinator's entrepreneurial mindset", according to the Deans. In all three clusters, the performance of the course coordinator is one of the drivers that less count for value in the HEI's Human Capital. However, as a paradox, the course coordinator would be the main articulation link between the education proposal of each course / unit and the corporative goals set by the upper management.

Due to the importance of the strategic alignment between the administrative and the pedagogical areas, further studies along with the course coordinators of this HEI ought to be developed. In this future research, the convergence of opinion regarding the drivers that create more value to a HEI could be accepted or not.

As theoretical and for practitioners implications, we have identified that there may be an interesting dynamic between the lie models of the three Deans' clusters: (i) the Operatives, more focused on the student's relationship with the internal environment; (ii) "Corporatives", more focused on the relationship between results and investors; and (iii) "Academics", open to society and long-term performance.

Both "Academics" and "Corporatives" would exert some sort of organizational pressure on the "Operatives" purposely so-called facing the term "Operationals", which would indicate a greater emphasis on results than on the one facing actual production process.

The "Corporatives" would seek to impose on the "Operatives" an even greater commitment with resource allocation and margin generation, while the "Academics" would propose over the "Operatives" an agenda of proximity to the network effects related to the Knowledge Economy and sustainability development.

Only time can tell the effects of this Deans' clash — lack or slack of resources for the operations —, but it is worth remembering that HEI itself hired and enrolled its Deans in management development courses to achieve more management team response.

What Deans' team response is expected? Well this is a strategic issue, for which there is no disclosure on the part of HEI, at least in the scope of this study. 


\section{References}

Awad, F. M. (2010). A estruturação e a gestão do capital intelectual na. Universidade de Passo Fundo: uma análise a partir do modelo de navegador de Stewart. Dissertação (Mestrado em Administração) - Universidade Regional do Noroeste do Estado do Rio Grande do Sul, Ijuí-RS.

Bontis, N. (2003). Intellectual capital disclosure in Canadian corporations. Journal of Human Resource Costing and Accounting, 7(1/2), 9-20.

Bontis, N., Crossan, M., \& Hulland, J. (2002). Managing an organizational learning system by aligning stocks and flows. Journal of Managerial Studies, 39, 437-69.

Brambilla, F. R., \& Bontis, N. (1999). Managing Organizational Knowledge by Diagnosing Intellectual Capital: Framing and advancing the state of the field. International Journal of Technology Management, 18(5/6/7/8), 433-462.

BRASIL. (1996c). Lei 10.861, de 14 de abril de 2004. Institui o Sistema Nacional de Avaliação da Educação Superior - SINAES. Diário Oficial [da] República Federativa do Brasil, Brasília, DF, 20 mar. Seção 1, p. 4686.

. Lei no 10.861, de 14 de Abril de 2004. Institui o Sistema Nacional de Avaliação da Educação Superior e dá outras providências. Retrieved 11.03.2016 from http://portal.mec.gov.br/arquivos/pdf/leisinaes.pdf

Carvalho, C.H.A. (2013). A mercantilização da educação superior brasileira e as estratégias de mercado das instituições lucrativas. Revista Brasileira de Educação, 18(54). Rio de Janeiro Jul/Set.

Casartelli, A.O., Rodrigues, A.C.M., Bittencourt, H.R., \& Garobotti, V. (2010). Inteligência estratégica em Instituições de Ensino Superior. Perspectivas em Ciência da Informação, 15(2), 183-197, maio/ago.

Consultoria, CM. Fusões e Aquisições no ensino superior. 2012. Retrieved 11.03 .2016 from http:/www.cmconsultoria.com.br/arquivos/GraficoAquisicoesIES.pdf

Damacena, C. (2012). Estudo etnometodológico da cocriação de valor no ensino superior privado de administração com base na lógica dominante do serviço em marketing. Revista Brasileira de Marketing, 11(3), $124-153$.

Dias, Sergio Roberto (coord.) et al.. (2006). Gestão de Marketing. São Paulo: Saraiva.

Edvinsson, L., \& Malone, M. (1997). Intellectual capital: realizing your company's true value by finding its hidden brainpower. New York: Harper Business Publisher.

Garcia, M. (2005). Revista Ensino Superior. São Paulo, (77), 41-43, fev.

González, M. M. C., \& Sallero, F. J. S. (2010). Gestão do conhecimento na gestão estratégica dos recursos humanos no setor da aqüicultura da Espanha. Revista Brasileira de Gestão e Desenvolvimento Regional, 6(1), 137-164, Taubaté, SP, Brasil, jan-abr.

Hair, Jr., Joseph, F., Babin, B., Money, Arthur H., \& Samouel, P. (2005). Fundamentos de métodos de pesquisa em administração. Porto Alegre: Bookman.

Holanda, Jr; A., Farias, I.Q., \& Gomes, D.M.O.A. (2006). O valor do cliente como elemento de marketing para Instituições de Ensino Superior. BASE - Revista de Administração e Contabilidade da Unisinos, 3(2), 102-111, maio/agosto.

IADE. (2003). Modelo Intellectus: medición y gestión del Capital Intelectual. C.I.C. IADE. (UAM). Madrid. INEP. (2013). Censo da Educação Superior 2011, Resumo Técnico. Brasília: Instituto Nacional de Estudos e Pesquisas Educacionais Anísio Teixeira. Retrieved 11.03.2016 from http://download.inep.gov.br/educacao_superior/censo_superior/resumo_tecnico/resumo_tecnico_censo_educaca o_superior_2011.pdf

INEP. (2013). Sinopses Estatísticas da Educação Superior - Graduação. Retrieved 11/03/2016 from http://portal.inep.gov.br/superior-censosuperior-sinopse

Janissek-Muniz, R., Lesca, H., \& Freitas, H. (2006). Inteligência estratégica antecipativa e coletiva para tomada de decisão. Revista Organização em Contexto, 2(4), 92-118.

Kaplan, R.S., \& Norton, D.P. (1992, Jen-Feb.). The Balanced Scorecard - measures that drive performance. Harvard Business Review, 72-79.

Kaplan, R.S., \& Norton, D.P. (1997). A Estratégia em Ação: Balanced Scorecard. Rio de Janeiro: Campus. 
Kaplan, R.S., \& Norton, D.P. (2004). A Strategy Maps: converting intangible assets intangible outcomes. Harvard Business Publishing Corporation. Retrieved 09.04.2015 from http://books.google.com.br

M'pherson, P., \& Pike, S. (2001). Accounting, empirical measurement and intellectual capital. Journal of Intellectual Capital, 2(3), 246-260.

Machado, E. (2008). Capital Intelectual: um estudo nas instituições ibéricas. Coimbra. Sodlivros. 2008.

Meyer Jr. Pascucci, \& Mangolin. (2012). Gestão estratégica: um exame de práticas em universidades privadas. $R A P$, 46(1), 2002.

Mintzberg, H. (1995). Criando organizações eficazes: estruturas em cinco configurações. São Paulo: Atlas.

Monteiro, C., \& Braga, R. A bolha especulativa do ensino superior privado. Retrieved 11.03.2016 from http://www.aprendervirtual.com/ver_noticia.php

Morgan, G. (1980). Paradigms, metaphors, and puzzle solving in organization theory. Administrative Science Quarterly, 25(4), 605-622.

Moura, S. N., Ferreira, H. F. N., Sousa, J. L. R., \& Ponte, V. M. R. (2005). O Valor do Intangível em Instituições de Ensino Superior: Um Enfoque no Capital Humano. Revista Brasileira de Gestão de Negócios FECAP, 7(8), Agosto.

Payne, A. F., Storbacka, K., \& Frow, P. (2008). Managing the Co-Creation of Value. Journal of the Academy of Marketing Science, 36, 83-96.

Peroba, T. L. C. (2013). Modelo de avaliação de Capital Intelectual para os cursos de mestrado profissional em administração: uma contribuição para a gestão das instituições de ensino superior. Tese de Doutorado. FGV.

Prahalad, C. K., \& Ramaswamy, V. (2003). The New Frontier of Experience Innovation. MIT Sloan Management Review, $\quad 4(44), \quad 12-18 . \quad$ Retrieved 11.03 .2016 from https://www.evernote.com/shard/s7/sh/bf8c75fe-8523-42e9-ad65-0e72f40f407e/5003a5ba28daf0fe617bcc3373 6a0335

Rosa, A. R. (2006). O Brasil não é para amadores: estado, governo e burocracia na terra do jeitinho. Cad. EBAPE.BR, 4(1), 01-02. $\quad$ Retrieved 11.03 .2016 from http://www.scielo.br/scielo.php?script=sci_arttext\&pid=S1679-39512006000100012\&lng=en\&nrm=iso

Silva Junior. (2014). Políticas públicas para a educação superior: a avaliação, a regulação e a supervisão de IES privadas em debate. Ensaio: aval. Pol. Públ. Educ., 22(82), 215-240.

Sirvanci, M. (1996). Are the students the true customers of higher education?. Quality Progress, 29(10), 99-102.

Soares, M. S. A. (coord.). (2002). A educação superior no Brasil. Instituto Internacional para a Educação Superior na América Latina e no Caribe IESALC - Unesco - Caracas. Porto Alegre. Retrieved 11.03.2016 from http://www.Ipp-uerj.net/olped/documentos/0075.pdf

Stewart, T. A. (1998). Capital Intelectual: a nova vantagem competitiva das empresas. Rio de Janeiro: Campus.

University of Louisville. Dean's Position Description. Retrieved 11.03.2016 from http://louisville.edu/education/about/dean/about/dean-position 